\title{
Law and Method
}

DOI: 10.5553/REM/.000009

\section{Law and Functionalism: The Limited Function of Law}

\section{Bert van Roermund*}

\section{Aanbevolen citeerwijze bij dit artikel}

Bert van Roermund, 'Law and Functionalism: The Limited Function of Law', ReM 2015-04, p.

\section{Introduction}

If we want to answer the question what sense a functionalist approach to law makes, we have to take a position in a more general debate in epistemology: what does it mean to take a functionalist approach to some phenomenon P in general? Think of such phenomena as a heart beating in a living organism, the rise and fall of golf clubs in certain countries, or, indeed, the gradual 'securitization' of immigration law in the EU. What exactly is 'explained' in a functionalist account of these phenomena? And is it the same thing that is explained in all of them? Not too long ago, Philip Pettit offered an elegant hypothesis by answering that functionalist explanations in social sciences are different from functionalist explanations in, for instance, evolutionary biology, in that they contribute to understanding the resilience of certain properties in a system rather than the presence of these properties. I will follow him in this, but not without a further distinction between two meanings of 'resilience' that seems crucial to me. I will distinguish a mechanical meaning of resilience in terms of 'remaining the same' from a teleological meaning in terms of 'preserving oneself'.

In the second part of the paper I will bring a teleological interpretation of 'resilience' to bear on the functions that are ascribed to law and argue that it comes in favor of a rather limited function. In contradistinction to wide views ('protecting basic moral values', 'implementing public policies', 'steering individual and group behavior', '(re-) allocating rights') I defend a narrow view: law (in Western societies) is designed to end or prevent conflicts that are potentially disruptive of society, by authoritative decision-making. I 
will back this up by arguing (1) that ending/preventing conflict does not entail 'solving', though solving a conflict is a perfect way to end/prevent it; (2) that not every conflict is the law's business, though even small conflicts may become socially disruptive; (3) that any theory of law (functionalist, evolutionist, economist) has to usher in an account of authority, though arguably (pace Hobbes) authority cannot be exercised without (practical) knowledge claims regarding a society's overall well-being. I show why this narrow view is the best explanation of some peculiar features of law (a.o., procedures, rituals, time constraints, discretion, stare decisis, etc.), and submit that it should lead to modesty in the minds of legislators, in particular.

\section{Functionalism}

If we take 'functionalism' as characterizing, first and foremost, a methodology in building theories (in our case theories on law), one of the basic questions is whether, to what extent, and on what account, it may be called 'functional' as distinct from other theories. What we would like to know is, in particular, how such a methodology may usher in theories that are neither purely causal nor purely interpretational. I submit that the answer crucially hinges on what it is exactly that a functionalist approach purports to describe, explain, and even predict. Here as elsewhere in science, object commands method. Hence: what is targeted in a functionalist approach?

\subsection{Functionalism and resilience}

Many years ago Ernest Nagel ${ }^{\mathbf{1}}$ argued that functional approaches are particularly apt (if at all) to give an account of so called self-regulating systems, where consequences feed back into the system and become part of the explanation of why the system is as it is. Law seems to be such a system (Luhmann 1987). By slithly adapting Dorothy Emmet's summary of Nagel's formula (with $L$ for a legal system) we may render it as follows:

'Let $L$ be a system and $E$ its environment, and let $L$ be functional, self-maintaining, or directively organized with respect to a trait (property, state, process), G. Let $L$ undergo a series of alterations terminating in $\mathrm{G}$. Let there then be some fairly extensive class of changes either in $E$ or in certain parts of $L$. Then, unless $L$ contains some mechanism that produces effects compensating for these changes, $L$ will cease to exhibit $\mathrm{G}$ or the tendency to acquire $\mathrm{G} .{ }^{2}$

Nagel added that, in order for this formula to work, $L$ must be specified with regard to the parts that are causally relevant to the state of $\mathrm{G}$, including the return effects of those parts that have the 'function' of maintaining $L$ in $\mathrm{G}$ against changes. He held that very few functional analyses in sociology would meet these standards of 
specification.

These comments, I submit, are largely in line with some arguments made much later by Philip Pettit, on functional explanation targeting the 'resilience' of a system. Like Nagel, Pettit observes that for most functional explanations in social sciences there is no mechanism $\mathrm{M}$ to cite, akin to the natural selection mechanism in biology, explaining the presence or emergence of properties $\mathrm{P}_{\mathbf{1}}, \mathrm{P}_{\mathbf{2}}, \ldots \mathrm{P}_{\mathbf{n}}$ of $L$ as it evolves through state G. ${ }^{\mathbf{3}}$ However, they do explain the resilience of $L_{\mathbf{G}}$ under possible changes $c_{1}, c_{2} \ldots c_{n}$, for which an actual mechanism is not required. Such changes do not have to occur. They may remain entirely counterfactual. In these cases the mechanism will remain virtual. What we need to show is that the mechanism emerges as soon as the changes occur. Even if the presence of $L_{\mathbf{G}}<\mathrm{P}_{\mathbf{1}}, \mathrm{P}_{\mathbf{2}}, \ldots \mathrm{P}_{\mathbf{n}}>$ is not illuminated by the function it serves, the function will explain why $L$ stays around over time, in spite of the changes in the system or its environment. ${ }^{4}$ For instance, it will explain why the system returns to some form of equilibrium, or to some form of adaptation or 'fit', or to some form of reproduction, or to some range of temperatures, etc. In brief, a functional explanation describes some properties $\mathrm{P}_{\mathbf{1}}, \mathrm{P}_{\mathbf{2}}, \ldots \mathrm{P}_{\mathbf{n}}$ as part of a mechanism $M$ that (1) causes system $L$ to stay in state $G$, should changes $c_{\mathbf{1}}, c_{\mathbf{2}}, \ldots c_{\mathbf{n}}$ in $L$ or its environment $E$ push to the contrary; but (2) that remains virtual as long as $c_{\mathbf{1}}, c_{\mathbf{2}}, \ldots c_{\mathbf{n}}$ do not occur. So, suppose speaker S says:

[1] In the body the heart is pumping to circulate the blood,

$\mathrm{S}$ is not committed to believe that there would be no circulation of the blood without a heart. In a specific case, the blood could also be circulated by a machine external to the body. Moreover, if a heart would stop to circulate blood, it would still be a heart. What $\mathrm{S}$ does believe, however, is that a body is resilient against certain changes in its environment or its internal make-up because the mechanism of the heart manages to keep circulating the blood. Or another example, if $\mathbf{S}$ says:

[2] In Western society the golf club is for greasing business relations,

$\mathrm{S}$ neither means that business in Western society would not be greased without golf clubs nor that something is not a golf club if it does not grease business relations to the benefit of society. S only means that Western society remains in a relatively steady state because the mechanism of the golf club manages to grease business relations.

It is not far-fetched to conceive of 'justice' in terms of resilience. I deliberately write 'justice' rather than 'law', as the former term may 
refer either to an institution in place in a certain society ('access to justice', 'administration of justice') or to the aspiration(s) that underlie having such an institution in the first place. To start with the latter, the hallmark of justice is the aspiration 'to give everyone their due'. Traditionally, this comes under two headings: (1) to restore balances by attributing a penalty to a crime, a payment to a performance, a remedy for an injury, etc.; (2) to distribute a good fairly over a set of agents. As such distributions never start as if it were the first day of creation, they are in fact invariably redistributions: they interfere in existing distributions. In other words, these redistributions are moves from one situation regarded as less just towards one that is regarded as more just. They speak to the resilience of a society hovering between certain values of the same aspiration variable 'justice'. In this, they resemble the operations under the other heading, i.e., 'restoration'. There is a host of alternative labels for it, in particular 'commutative justice', 'corrective', and even 'retributive' justice (in a broad sense of 'retribution'). They all bring to the fore that by aspiring to this value, society is supposed to bounce back from a less just state to a more just state, thus constantly trying to find its balance.

Resilience captures this double picture as it is deeply entrenched in a time-honored moral tradition. But resilience is also at the core of justice in the institutional sense of the term. In that case the institution of law, much like the golf club, is the mechanism that is supposed to keep social relationships between certain critical values. Rousseau, among others, sometimes seems to favor this view, e.g., when he submits that 'the law' should aim at a certain form of equality among the members of society: neither should anybody be so poor that he feels forced to sell himself, nor should anybody be so rich that he feels able to buy someone else. ${ }^{\mathbf{5}}$ Or when he advises that there is an easy marker of good government: the growth of a population, but surely within certain critical limits commanded by the environment. ${ }^{6}$ Here again, resilience to a steady state, dynamic as it may be, is the heart of the matter.

By concentrating on law as a mechanism of resilience, functionalism steers away from encompassing views on law that, important as they may be in their own right, contribute little to methodology in legal scholarship. Functionalism can afford to remain rather neutral between, for instance, systems theory, natural law theory, legal pragmatism or legal positivism. When it comes to the range between critical values that is regarded as a steady state to which society would bounce back if brought outside of this range, it is pretty immaterial where this range hails from: e.g., the system itself, bio-nature, rationature, the will of an authority. These are things that matter in a different realm of questions, in particular philosophical ones. ${ }^{7}$ Obviously, such philosophical stances will offer different assessments of functionalism from their own perspectives. However, this hardly affects how a legal scholar goes about his or her own business. It does 
not penetrate their method ${ }^{\mathbf{8}}$ while functionalism does. Functionalism focuses on the mechanism that explains the workings of these barely visible flippers in the pinball machine, that keep the ball of society rolling. But there is one crucial distinction yet to be made.

Such a mechanism may or may not be taken up as a role by an agent involved. Not by the heart because it is not an agent. But surely by the golf club, which is an agent, in particular a collective agent. Collective agency comes with so-called plural (or collective, or joint) intentions. ${ }^{9}$ It also comes with representation, since 'there is no "we" that can say "we". ${ }^{10}$ Thus, fulfilling this role of greasing business relations may become something the golf club, golf clubs in general, or even (a representative of) society may acknowledge, quite apart from S's observation. Indeed it may even become the golf club's mission, i.e., an explicit intention. Here is where resilience dovetails into two notions.

\subsection{Two meanings of resilience}

Intentions entail reflexive terms. If I intend to take my bag, e.g., thinking [3]

[3] I'm going to take my bag,

then - whatever my neuro-cognitive 'wiring' may be - I consider myself to be both the framer of the intention and the would-be agent of the action. The point is that the framer and the agent are not just 'the same' but that they are the same from a first-person viewpoint that is involved in the intention. If I ascribe an intention to another person, as in (the somewhat elaborate form)

[4] Mrs. B intends that she* take her ${ }^{\star}$ bag,

then I imply, by virtue of the quasi-indicators 'she*' and 'her"' that Mrs. B is able to make first-person references with regard to her (herself) taking up her (her own) particular bag. This would be characteristically different from the implications of an utterance like

[4'] Mrs. B intends that Mrs. B take her bag,

since [4'] may be true even in case Mrs. B does not know that she is Mrs. B. ${ }^{11}$ Reflexive reference crucially distinguishes [4] from [4']. On the basis of this distinction we may recognize the time-honored difference between identity as sameness and identity as selfhood, for which some languages even have different referential devices. ${ }^{\mathbf{1 2}}$ And this again is firm ground to distinguish resilience as preservation of properties $\left\langle\mathrm{P}_{\mathbf{1}}, \mathrm{P}_{\mathbf{2}}, \ldots \mathrm{P}_{\mathbf{n}}>\right.$ in a system $L$, from resilience as selfpreservation by an agent $A$ in $L$ in terms of properties $<\mathrm{P}_{\mathbf{1}}, \mathrm{P}_{\mathbf{2}}, \ldots \mathrm{P}_{\mathbf{n}}>$. 
Note that the latter cannot gain any meaning without connecting the thin reference to a 'self' to substantive properties and testing if these connections remain 'the same' (idem) over time. But then again, all this connecting and testing build up to personal identity as 'a self' (ipse) only if such sameness is acknowledged from a first-person vantage point. No such acknowledgment is required to claim or test sameness of properties pure and simple, nor for that matter, to engage in more complicated cognitive endeavors of a similar kind, like establishing facts or causal relations.

I submit that reflexivity is also crucial in making a distinction between two encompassing discursive modes with regard to resilience. One we could call functionalism proper (F-mode), in which resilience is conceived as preservation, identity as sameness, and explanatory patterns as causal mechanisms running under certain (counterfactual) conditions, as sketched by Pettit. This is why we may characterize it as a 'mechanical' mode. The other we could call teleology proper (Tmode), where resilience is self-preservation, identity is taken as selfhood, and explanatory patterns are presented in terms of the sense they make, e.g., in the established settings of plural intentional action that we usually call 'institutions'. The dominant perspective of F-mode is a third-person one, while the perspective of T-mode is dominated by the first-person viewpoint. ${ }^{\mathbf{1 3}}$

Two important observations have to be made in addition to this distinction. The first is that these are indeed discursive modes. This entails that they do not register at the purely lexical level. There are no words that exclusively belong to one or the other mode. In a more positive vein one should be aware that words like 'purpose', 'goal', 'aim', 'meaning', indeed even 'function' may circulate in either mode. It requires further analysis to detect how they have to be read or heard. The second observation is that it is common to switch between modes, and that again there are two ways of doing so. One is the inadvertent way, by which the speaker may cause a considerable amount of confusion. The other is the sophisticated way, exploring the internal links between the two modes.

It is not difficult to see which internal links allow for modulation between F-mode and T-mode in either direction. To some extent, as we saw, T-mode is predicated on F-mode. For instance, to return to an earlier example, the golf club cannot really be committed to the mission of greasing business relations if it is not prepared to critically assess the underlying mechanism(s) that make(s) people more overt to business exchanges while playing this particular game. Only on the basis of this kind of assessment it will be able to formulate a viable mission statement. So at certain points their discourse in T-mode will revert to F-mode. But this is a two-way street. F-mode ushers in Tmode in institutional contexts, as institutions, generally speaking, are 
default settings of behavior dubbed meaningful (making sense) in and by a given society. Often such meaningfulness is rendered in terms of values, interests, or (more or less shared) preferences. ${ }^{\mathbf{1 4}}$ The golf club may also check the mechanisms it appears to be part of against its mission statement and decide that it will steer away from some of them. It may well be that it remains unaware of some of these functional mechanisms, and the sole fact that it becomes aware of them is perhaps a necessary but certainly not a sufficient condition for distancing itself from them.

In a similar vein, a legal order - its officials and its subjects - may be studied in both modes and profit from their interrelations. Social and behavioral sciences like economics, (social) psychology, sociology, evolutionary theory, and their ilk, will theorize the mechanisms underlying law's 'mission statement'. But the implications of such a statement with regard to certain areas of socio-political life, or specific problems arising in these areas, are the subject matter of a teleological angle on a legal order. Describing, explaining and (even) predicting these implications has always been the task of legal scholarship. Importantly, in spite of lexical fuzziness and conceptual interrelations between the two modes, neither of them should be collapsed into the other.

\section{Wide and narrow views on the function of law}

We are now equipped to turn to the institution of law and see how its function(s) may be assessed in view of its resilience, modulating between F-mode and T-mode. I will first discuss some views that ascribe very wide functions or purposes to law, but for which we can hardly find an appropriate mechanism that offers an account of salient characteristics of a resilient legal order. Then I will turn to a more limited function, one that satisfies this condition and allows for a properly teleological account of law that is sensitive to such a mechanism. Throughout this section I will stick to the belief that there is no lexical basis to distinguish F- from T-mode, as these are patterns of discourse that distribute the same lexical elements in different ways.

\subsection{Widely held (too) wide views}

Wide normative claims on the function of law abound, and they are played around not just in jurisprudential circles. Take, for instance, the final phrase from a leaflet presenting the 'Agenda for the Dutch Judiciary 2015-2018: 'Law makes social life possible.' It very much resembles our golf club example. Of course, this promo phrase hovers (deliberately, I presume) between necessary and sufficient conditions, but the innuendo cannot be missed. Law is instrumental to social life in all its richness, or so the message is. I will explain, in due time, why 
I think this is an infelicitous overstatement. But let us look first at a shortlist of similar, explicitly argued, views I met over the last decade or so, regarding the ultimate function of law. Law is alleged to be there, in the final analysis, for the sake of:

i. regulating individual and group behavior ${ }^{\mathbf{1 5}}$

ii. implementing public policies $^{\mathbf{1 6}}$

iii. (re-)allocating rights; ${ }^{17}$

iv. protecting basic moral values; ${ }^{\mathbf{1 8}}$

v. ordering basic needs and the satisfaction thereof.

It would neither be difficult to extend the list, nor to refer to more (and more specific) publications. But to avoid irrelevant discussions let us try to be neither be exhaustive nor selective. This shortlist will do to get the picture. Most lawyers will concede that law has several functions, and/or that some specific function is not the exclusive domain of law. That's fine. But my concern is twofold: if a function is not the exclusive domain of law, what is the specific way in which law enters the domain? And if various functions should be ascribed to law, what function should be leading when push comes to shove, i.e., when two or more functions collide? Note that the normative ring of these questions primarily indicates that we are looking for an answer from a first-person (plural) viewpoint; the vantage point of a 'we' trying to pinpoint 'what law is for' in the society they call 'our'. It is from this vantage point that we will be able to look back at the underlying mechanism and to various functions that 'we' would like to take on board, or not.

Here are some examples. There is no point in denying that law should regulate behavior in society. Indeed it does. E.g., in the face of biotechnological developments it regulates the patentability of the use of human embryos for commercial purposes, ${ }^{\mathbf{1 9}}$ or of certain methods to harvest human stem cells that entail the destruction of fertilized ova in the blastocyst stage. ${ }^{\mathbf{2 0}}$ Or it sanctions certain technological devices (such as road bumps or encrypted codes) that make it impossible (or at least very expensive) to defer from a desirable pattern of behavior. But then, lots of social institutions regulate human behavior. They do so, for instance, by providing education, or by organizing a market, or by promoting a religion, or by constructing certain technological devices, or by simply continuing a habit under a certain type of circumstances. So what is law doing in this already overcrowded area? The question is often ignored, or even rejected as old-fashioned 'essentialism'. One rather prefers to invert the definition: if law is a species of regulating behavior, why not say that all regulation of 
human behavior may appear to be law. 'Soft law' seems to prove the point. But in fact soft law proves my point, i.e., my concern. I acknowledge that some efforts to regulate behavior (e.g., a program of subsidies by a semi-governmental body) may turn out to be legally binding in hindsight, while just governmentally advisable in foresight (which is what soft law is mainly about). But my question is: What value is added to such a program at the moment it is sanctioned by law? And the answer does not lie entirely with the sanction as such, since the sanction itself is embedded in a wider set of considerations and constraints that are dubbed 'legal'.

Apart from the exclusivity issue there is the priority issue. It is all well and good to acknowledge all functions that may credibly be attributed to law. But different functions of law may clash, and then the question is whether some functions are more important than others, so that they become leading in cases of conflict. These conflicts are quite common. There is little doubt, for instance, that law is (and should be) instrumental in implementing public policies; e.g., it should serve the government in warranting a certain level of security to the public against terrorist attacks. Obviously, this policy may interfere with another function of law, like attributing and enforcing certain basic rights to individual members of the polity, e.g., the right to privacy. It is common place to say that, ceteris paribus, the right to security and the right to privacy ought to be 'balanced'. That's fine. But what the metaphor of the balance leaves out - here as elsewhere - is what function of law would take the role of the gravity force in establishing the balance? There is, I submit, nothing essentialist about the question which function of law is leading 'ultimately', or 'on the final count of things', or 'when push comes to shove'. Perhaps, these more candid phrases are easier to accept than a dogma or two on 'the essence of law'. But even the most fanatic supporter of Wittgenstein's famous 'family resemblances' will concede that it hinges on the possibility to single out at least some typical traits for a family, or else also this metaphor will evaporate into thin air. Note that I do not say that we must find one all-embracing function for everything called law. But what I do assert is that we are able (indeed, ought) to ask what a specific (set of) legal norm(s) is about 'in the end', or 'what sense' it ultimately makes. Whether we call this a function or an idea, a purpose or a pursuit, is rather immaterial.

Both the priority issue and the exclusivity issue suggest that there is reason to inquire about what should be regarded as the ultimate function of law? Could one of the items (i) - (v) be considered as serious candidates for this role? I think none of them would qualify, even if I grant that law may have these and other functions subordinated to its core business. But none of them is the law's core business in the sense above. Let me briefly point to some difficulties with each of them. 
(i) regulating individual and group behavior.

Although law belongs to the genus of 'doing things with rules'21 and although it is therefore crucial to understand rule following in general in order to understand law $^{\mathbf{2 2}}$ this function needs to be narrowed down by a specific mode of regulation characteristic of law, as already suggested.

\section{(ii) implementing public policies}

Law as the privileged instrument to implement public policies is a popular functional definition of law. But as a view that reduces the function of law to a pure instrument of politics, it easily goes astray. Law should also protect people against certain policies. To this end it should prioritize certain policies in such a way that they become 'trumps' in the usual bargaining of trade-offs that characterizes the political process. ${ }^{\mathbf{2 3}}$ Without the specific quality generated by this transformation, (ii) is too wide, even if it is granted that the transformation itself is a form of implementing a public policy. On a wider canvass the argument should turn against the view that law is the sum total of norms enacted, applied and enforced by governmental authorities in the name of 'the public interest' or 'the common good'. The law also has a task to fulfill with regard to those who are excluded from 'the public' or 'the community' by dint of its self-inclusion. ${ }^{24}$

\section{(iii) (re-)allocating rights}

At first sight this is the core function of law, in particular if we see rights the Hohfeldian way, distinguishing between various meanings of 'right' and their systemic relationships with duties, capabilities, and liabilities. But even then it is a view that quickly becomes circular. I.e., if we define the function of law in terms of (allocating) rights, and then have to determine rights, capabilities, and their ilk, by reference to the function of objective law, we have gone full circle. And it seems that we cannot escape from this conundrum, as long as rights are seen not as sheer interests but as interests worthy of protection by law; or capabilities not as sheer powers but as competences attributed by law. In other words, (iii) is perhaps fine as a doctrinal view but not as a philosophical one.

\section{(iv) protecting basic moral values}

In societies where the notion of 'the good life' is an essentially contested one, this view on the basic function of law soon loses its attractiveness. Or, to put it the other way around, law that would not be able to intervene in a violent conflict between morally deeply divided parties because of its own moral parti pris, would hardly have any functional merit at all. There are good, even morally good, reasons 
for law to keep morality at bay when it comes to its role in society. In particular value-based conceptions of morality are difficult to accommodate directly by a legal order, as the German experience with Wertjudikatur and the critique of Wertungsjurisprudenz show. ${ }^{25}$

\section{(v) ordering basic needs and the satisfaction thereof}

This is probably the most down-to-earth view on the function of law. And again, there is no point in denying that law, in whatever function it may appear, has to take into account what Hart called 'the minimum content of natural law'. ${ }^{26}$ It does not have to cater to basic needs itself, obviously. But it should see to it that basic needs are presented and satisfied in an orderly way, given the constraints that people are born into, like limited resources, limited knowledge of consequences over time, limited strength of will, etc. Even (or particularly) if we leave the (nation) state-centered paradigm of law behind, here is a touchstone for the function of law in society at large. But once more the view is too wide, and too unspecific. It requires a deeper analysis regarding its implications, e.g., criteria that distinguish 'order' from 'disorder', or 'basic' from 'higher' needs. I submit that this most down-to-earth view may well be the most puzzling one. ${ }^{27}$

In conclusion we find that none of these wide, and widely-held, views on the ultimate purpose of law is sufficiently specific to offer a stronghold in cases where different functions collide or where one function is served by other agents and institutions than the juridical ones.

\subsection{An alternative narrow view}

I would like to contrast these wide views with a narrower one: at the core, law (in Western societies) is there to end or prevent conflicts that are potentially disruptive of society, by authoritative (legislative, administrative, or judicial) decision-making. Before I go on to argue why this, admittedly traditional, view is more adequate than its wideranging competitors I would like to clarify how rich it is in its narrowness, thus straightening out some misunderstandings.

(i) Ending/preventing conflict does not entail 'solving' the underlying problem, though solving the underlying problem is a solid way to end/prevent a conflict. An important parameter of satisfying solutions is 'justice' or 'fairness', preferred values that are relevant not only in law but also in politics, economics, and ethics. The intention to go beyond the mere end of stopping or curbing a conflict and address the underlying issue explains why there is an increasing interest in Alternative Dispute Resolution (ADR), often 'under the shadow of the law'. It also explains why judges in family law take far more liberty to set formalities aside and go to the heart of the matter than in, say, tax 
law. But often the law is reluctant to tackle the underlying problem; it settles for just stopping or curbing a fight. And we should not regard this as a failure on the part of the law. There is wisdom in the old saying 'lites finiri oportet' (fightings should stop) because, often enough, a way of dealing with the problem will only be found, if at all, if and when parties return to the practice of daily life instead of staying at the meta-level of dispute. Doing the walk rather than the talk is often important in finding a way out of a predicament in human life, for the simple reason that a lot of our knowing-how (i.e., practical knowledge) is tacit, embodied, and conditional on actual situations. ${ }^{\mathbf{2 8}}$ For instance, when I am hesitant about the correct spelling of a word, it does not help to think harder; it helps to stop thinking and to start writing it; chances are that then I will know. In a similar vein, problems in social relationships may profit from stopping the quarrelling on both sides and getting on.

(ii) Not every conflict is the law's business, though even small conflicts may become socially disruptive. It is a sound sociological insight that conflicts in social relationships are not necessarily bad; they often deepen and enrich such ties. But conflicts, even small ones, tend to drift further and further away from a solution, i.e., get out of hand, the more argumentative fuel is brought to the fire by the parties involved. Indeed, even small conflicts tend to involve more and more parties, to the point where they may wreck whole societies. ${ }^{29}$ Law tries to monitor the type of conflicts that are potentially disruptive on a large scale. This, however, is very much dependent on cultural time and space. For instance, in secular society, blasphemy is unlikely to cause social disruption, whereas in religious societies it will do so quite predictably. As a consequence, there is very limited ground for (criminal) law to interfere in the former, while there is plenty of reason in the latter case. Also linguistic pluralism may be negotiated quite smoothly in one country (Switzerland) and give rise to one constitutional crisis after the other in another one (Belgium).

It requires political sensitivity to assess which conflicts should be engaged by law and which should not. From a judicial point of view, quite a few conflicts in private law root in hurt personal feelings, where damages are claimed for the sheer purpose of getting access to a verdict on 'guilt'. They are unlikely to grow to disruptive proportions by any 'slippery slope' argument. Moreover, slippery slope arguments themselves are not always appropriate. ${ }^{\mathbf{3 0}}$ But they are not insane either. From a legislative viewpoint, however, there is a persistent inclination to regulate in view of 'order' rather than 'peace', where the criteria of order are inspired by political priorities rather than the reduction of conflict. I would be hesitant to attribute the predicate 'law' to all these regulations. Many of these are political arrangements which should be left to the political process. 
(iii) A priori, there are many ways to end or prevent serious conflict in society, and not all of them are part of law; e.g., insulating or eliminating (one of) the antagonists in the conflict, or providing abundant resources. Law has a specific way with conflicts. It tries to stop or curb them by authoritative decision-making. Therefore, any theory of law (functionalist, evolutionist, economist, etc.) has to usher in an account of authority, quite apart from what is equally necessary, namely a theory of decision-making. For reasons of space, let me focus on the former, i.e., on the old saying quoted famously by Hobbes that it is authority rather than truth that makes law. ${ }^{\mathbf{3 1}}$

A lot of ground here is covered by Raz's 'service conception' of authority, which is basically an answer to the question what it is to 'follow' authority under conditions of (i) rationality and (ii) freedom. ${ }^{\mathbf{3 2}}$ I have little reason to take issue with this account here. It's just that I think that there is yet another question to be asked: what is it to acquire authority? To copy Raz's vocabulary, how do you give other agents reason to waive acting on the balance of their own reasons, and to believe that they will end up acting in accordance with the reasons that apply to them anyway if they follow your directives?

My answer is this; you should bring it about that they trust you with a certain knowledge in finding a way out of their predicament(s) which they do not have at their disposal (yet). It does not necessarily have to be theoretical, explicit and demonstrable knowledge. In most cases it is not. It may well be practical knowledge ('knowing how' rather than 'knowing that') and it may well be tacit, implicit, and embodied. Because it is practical it is easily confused with 'power': the power to find a way out of the predicament. But power is not the first thing at issue when the issue is a predicament. Arguably, the predicament may be canonically expressed as 'What should I/we do?' It is not, typically, 'What do I/we want to do?' For our wants may be short-sighted, illinformed, or weakly willed, even to the point where they become selfdestructive. We rather ask 'What is the right thing to do', given the kind of agent (singular or plural) we take ourselves to be everything being considered, or on the final count of things. Knowledge that leads us out of this predicament is, I submit, genuine (practical) knowledge - a mode of knowledge that comes (gradually) with experience, training, and critical feedback on consequences. It used to be called peritia. It comes far less, if at all, with accepting (learning) true propositions and rejecting false ones. People in predicaments of various kinds turn to people they trust with peritia in the specific circumstances at hand and call them 'authorities' who may be able to 'serve' them. Sometimes they will do this jointly, expecting a service that will benefit them jointly, i.e., that will be 'the right thing to do' for their society at large.

To evoke this kind of trust on the scale on society, and thus to acquire 
authority, one cannot build on the reasons pro and con a certain policy that are already available in society, since they articulate the very predicament that the parties involved desire wish to escape from. And so authority is acquired by pointing to a viable escape, i.e., to a hole in society's plural identity (as it is laid out in properties and preferences). This hole or, if one prefers, this porosity allows it to relate to its surrounding world in a new way for the future and yet retain the link to the past. In this sense, truth is indeed not the main source of law, while authority is. But from this it does not follow that authority can be accounted for without tying it in with an important mode of knowledge. And what is perhaps most important (and debatable...): once trust is evoked and has taken the form of a commitment to comply with authority for one's own benefit, it entails a default approval of coercion by the members of society. This is neither to say that authority is allowed to apply coercion in all domains of social life, nor that the approval cannot be withdrawn. But, by default, it would be self-contradictory to accept authority A in predicament $\mathrm{S}$ forfeiting the balance of one's own reasons, and then construing the balance of one's own reasons after all, as soon as one dislikes A's directives. I venture that, when it comes to law, coercion follows authority, rather than the other way around. ${ }^{33}$

\subsection{Two meanings of resilience}

Intentions entail reflexive terms. If I intend to take my bag, e.g., thinking [3]

[3] I'm going to take my bag,

then - whatever my neuro-cognitive 'wiring' may be - I consider myself to be both the framer of the intention and the would-be agent of the action. The point is that the framer and the agent are not just 'the same' but that they are the same from a first-person viewpoint that is involved in the intention. If I ascribe an intention to another person, as in (the somewhat elaborate form)

[4] Mrs. B intends that she* take her* bag,

then I imply, by virtue of the quasi-indicators 'she*' and 'her" that Mrs. B is able to make first-person references with regard to her (herself) taking up her (her own) particular bag. This would be characteristically different from the implications of an utterance like

[4'] Mrs. B intends that Mrs. B take her bag,

since [4'] may be true even in case Mrs. B does not know that she is Mrs. B. ${ }^{34}$ Reflexive reference crucially distinguishes [4] from [4']. On the basis of this distinction we may recognize the time-honored 
difference between identity as sameness and identity as selfhood, for which some languages even have different referential devices. ${ }^{35}$ And this again is firm ground to distinguish resilience as preservation of properties $\left\langle\mathrm{P}_{\mathbf{1}}, \mathrm{P}_{\mathbf{2}}, \ldots \mathrm{P}_{\mathbf{n}}>\right.$ in a system $L$, from resilience as selfpreservation by an agent $A$ in $L$ in terms of properties $\left\langle\mathrm{P}_{\mathbf{1}}, \mathrm{P}_{\mathbf{2}}, \ldots \mathrm{P}_{\mathbf{n}}\right\rangle$. Note that the latter cannot gain any meaning without connecting the thin reference to a 'self' to substantive properties and testing if these connections remain 'the same' (idem) over time. But then again, all this connecting and testing build up to personal identity as 'a self' (ipse) only if such sameness is acknowledged from a first-person vantage point. No such acknowledgment is required to claim or test sameness of properties pure and simple, nor for that matter, to engage in more complicated cognitive endeavors of a similar kind, like establishing facts or causal relations.

I submit that reflexivity is also crucial in making a distinction between two encompassing discursive modes with regard to resilience. One we could call functionalism proper ( $\mathrm{F}$-mode), in which resilience is conceived as preservation, identity as sameness, and explanatory patterns as causal mechanisms running under certain (counterfactual) conditions, as sketched by Pettit. This is why we may characterize it as a 'mechanical' mode. The other we could call teleology proper (Tmode), where resilience is self-preservation, identity is taken as selfhood, and explanatory patterns are presented in terms of the sense they make, e.g., in the established settings of plural intentional action that we usually call 'institutions'. The dominant perspective of F-mode is a third-person one, while the perspective of T-mode is dominated by the first-person viewpoint. ${ }^{\mathbf{3}}$

Two important observations have to be made in addition to this distinction. The first is that these are indeed discursive modes. This entails that they do not register at the purely lexical level. There are no words that exclusively belong to one or the other mode. In a more positive vein one should be aware that words like 'purpose', 'goal', 'aim', 'meaning', indeed even 'function' may circulate in either mode. It requires further analysis to detect how they have to be read or heard. The second observation is that it is common to switch between modes, and that again there are two ways of doing so. One is the inadvertent way, by which the speaker may cause a considerable amount of confusion. The other is the sophisticated way, exploring the internal links between the two modes.

It is not difficult to see which internal links allow for modulation between F-mode and T-mode in either direction. To some extent, as we saw, T-mode is predicated on F-mode. For instance, to return to an earlier example, the golf club cannot really be committed to the mission of greasing business relations if it is not prepared to critically assess the underlying mechanism(s) that make(s) people more overt 
to business exchanges while playing this particular game. Only on the basis of this kind of assessment it will be able to formulate a viable mission statement. So at certain points their discourse in T-mode will revert to F-mode. But this is a two-way street. F-mode ushers in Tmode in institutional contexts, as institutions, generally speaking, are default settings of behavior dubbed meaningful (making sense) in and by a given society. Often such meaningfulness is rendered in terms of values, interests, or (more or less shared) preferences. ${ }^{37}$ The golf club may also check the mechanisms it appears to be part of against its mission statement and decide that it will steer away from some of them. It may well be that it remains unaware of some of these functional mechanisms, and the sole fact that it becomes aware of them is perhaps a necessary but certainly not a sufficient condition for distancing itself from them.

In a similar vein, a legal order - its officials and its subjects - may be studied in both modes and profit from their interrelations. Social and behavioral sciences like economics, (social) psychology, sociology, evolutionary theory, and their ilk, will theorize the mechanisms underlying law's 'mission statement'. But the implications of such a statement with regard to certain areas of socio-political life, or specific problems arising in these areas, are the subject matter of a teleological angle on a legal order. Describing, explaining and (even) predicting these implications has always been the task of legal scholarship. Importantly, in spite of lexical fuzziness and conceptual interrelations between the two modes, neither of them should be collapsed into the other.

\section{Wide and narrow views on the function of law}

We are now equipped to turn to the institution of law and see how its function(s) may be assessed in view of its resilience, modulating between F-mode and T-mode. I will first discuss some views that ascribe very wide functions or purposes to law, but for which we can hardly find an appropriate mechanism that offers an account of salient characteristics of a resilient legal order. Then I will turn to a more limited function, one that satisfies this condition and allows for a properly teleological account of law that is sensitive to such a mechanism. Throughout this section I will stick to the belief that there is no lexical basis to distinguish $\mathrm{F}$-from T-mode, as these are patterns of discourse that distribute the same lexical elements in different ways.

\subsection{Widely held (too) wide views}

Wide normative claims on the function of law abound, and they are played around not just in jurisprudential circles. Take, for instance, the final phrase from a leaflet presenting the 'Agenda for the Dutch 
Judiciary 2015-2018: 'Law makes social life possible.' It very much resembles our golf club example. Of course, this promo phrase hovers (deliberately, I presume) between necessary and sufficient conditions, but the innuendo cannot be missed. Law is instrumental to social life in all its richness, or so the message is. I will explain, in due time, why I think this is an infelicitous overstatement. But let us look first at a shortlist of similar, explicitly argued, views I met over the last decade or so, regarding the ultimate function of law. Law is alleged to be there, in the final analysis, for the sake of:

i. regulating individual and group behavior ${ }^{38}$

ii. implementing public policies ${ }^{\mathbf{3 9}}$

iii. (re-)allocating rights; ${ }^{40}$

iv. protecting basic moral values; ${ }^{41}$

v. ordering basic needs and the satisfaction thereof.

It would neither be difficult to extend the list, nor to refer to more (and more specific) publications. But to avoid irrelevant discussions let us try to be neither be exhaustive nor selective. This shortlist will do to get the picture. Most lawyers will concede that law has several functions, and/or that some specific function is not the exclusive domain of law. That's fine. But my concern is twofold: if a function is not the exclusive domain of law, what is the specific way in which law enters the domain? And if various functions should be ascribed to law, what function should be leading when push comes to shove, i.e., when two or more functions collide? Note that the normative ring of these questions primarily indicates that we are looking for an answer from a first-person (plural) viewpoint; the vantage point of a 'we' trying to pinpoint 'what law is for' in the society they call 'our'. It is from this vantage point that we will be able to look back at the underlying mechanism and to various functions that 'we' would like to take on board, or not.

Here are some examples. There is no point in denying that law should regulate behavior in society. Indeed it does. E.g., in the face of biotechnological developments it regulates the patentability of the use of human embryos for commercial purposes, ${ }^{4^{2}}$ or of certain methods to harvest human stem cells that entail the destruction of fertilized ova in the blastocyst stage. ${ }^{43}$ Or it sanctions certain technological devices (such as road bumps or encrypted codes) that make it impossible (or at least very expensive) to defer from a desirable pattern of behavior. But then, lots of social institutions regulate human behavior. They do so, for instance, by providing education, or by organizing a market, or by promoting a religion, or by constructing certain technological 
devices, or by simply continuing a habit under a certain type of circumstances. So what is law doing in this already overcrowded area? The question is often ignored, or even rejected as old-fashioned 'essentialism'. One rather prefers to invert the definition: if law is a species of regulating behavior, why not say that all regulation of human behavior may appear to be law. 'Soft law' seems to prove the point. But in fact soft law proves my point, i.e., my concern. I acknowledge that some efforts to regulate behavior (e.g., a program of subsidies by a semi-governmental body) may turn out to be legally binding in hindsight, while just governmentally advisable in foresight (which is what soft law is mainly about). But my question is: What value is added to such a program at the moment it is sanctioned by law? And the answer does not lie entirely with the sanction as such, since the sanction itself is embedded in a wider set of considerations and constraints that are dubbed 'legal'.

Apart from the exclusivity issue there is the priority issue. It is all well and good to acknowledge all functions that may credibly be attributed to law. But different functions of law may clash, and then the question is whether some functions are more important than others, so that they become leading in cases of conflict. These conflicts are quite common. There is little doubt, for instance, that law is (and should be) instrumental in implementing public policies; e.g., it should serve the government in warranting a certain level of security to the public against terrorist attacks. Obviously, this policy may interfere with another function of law, like attributing and enforcing certain basic rights to individual members of the polity, e.g., the right to privacy. It is common place to say that, ceteris paribus, the right to security and the right to privacy ought to be 'balanced'. That's fine. But what the metaphor of the balance leaves out - here as elsewhere - is what function of law would take the role of the gravity force in establishing the balance? There is, I submit, nothing essentialist about the question which function of law is leading 'ultimately', or 'on the final count of things', or 'when push comes to shove'. Perhaps, these more candid phrases are easier to accept than a dogma or two on 'the essence of law'. But even the most fanatic supporter of Wittgenstein's famous 'family resemblances' will concede that it hinges on the possibility to single out at least some typical traits for a family, or else also this metaphor will evaporate into thin air. Note that I do not say that we must find one all-embracing function for everything called law. But what I do assert is that we are able (indeed, ought) to ask what a specific (set of) legal norm(s) is about 'in the end', or 'what sense' it ultimately makes. Whether we call this a function or an idea, a purpose or a pursuit, is rather immaterial.

Both the priority issue and the exclusivity issue suggest that there is reason to inquire about what should be regarded as the ultimate function of law? Could one of the items (i) - (v) be considered as 
serious candidates for this role? I think none of them would qualify, even if I grant that law may have these and other functions subordinated to its core business. But none of them is the law's core business in the sense above. Let me briefly point to some difficulties with each of them.

\section{(i) regulating individual and group behavior.}

Although law belongs to the genus of 'doing things with rules' $\mathbf{4 4}$ and although it is therefore crucial to understand rule following in general in order to understand law $\mathbf{4 5}$ this function needs to be narrowed down by a specific mode of regulation characteristic of law, as already suggested.

\section{(ii) implementing public policies}

Law as the privileged instrument to implement public policies is a popular functional definition of law. But as a view that reduces the function of law to a pure instrument of politics, it easily goes astray. Law should also protect people against certain policies. To this end it should prioritize certain policies in such a way that they become 'trumps' in the usual bargaining of trade-offs that characterizes the political process. ${ }^{46}$ Without the specific quality generated by this transformation, (ii) is too wide, even if it is granted that the transformation itself is a form of implementing a public policy. On a wider canvass the argument should turn against the view that law is the sum total of norms enacted, applied and enforced by governmental authorities in the name of 'the public interest' or 'the common good'. The law also has a task to fulfill with regard to those who are excluded from 'the public' or 'the community' by dint of its self-inclusion. 47

\section{(iii) (re-)allocating rights}

At first sight this is the core function of law, in particular if we see rights the Hohfeldian way, distinguishing between various meanings of 'right' and their systemic relationships with duties, capabilities, and liabilities. But even then it is a view that quickly becomes circular. I.e., if we define the function of law in terms of (allocating) rights, and then have to determine rights, capabilities, and their ilk, by reference to the function of objective law, we have gone full circle. And it seems that we cannot escape from this conundrum, as long as rights are seen not as sheer interests but as interests worthy of protection by law; or capabilities not as sheer powers but as competences attributed by law. In other words, (iii) is perhaps fine as a doctrinal view but not as a philosophical one. 
In societies where the notion of 'the good life' is an essentially contested one, this view on the basic function of law soon loses its attractiveness. Or, to put it the other way around, law that would not be able to intervene in a violent conflict between morally deeply divided parties because of its own moral parti pris, would hardly have any functional merit at all. There are good, even morally good, reasons for law to keep morality at bay when it comes to its role in society. In particular value-based conceptions of morality are difficult to accommodate directly by a legal order, as the German experience with Wertjudikatur and the critique of Wertungsjurisprudenz show. ${ }^{48}$

\section{(v) ordering basic needs and the satisfaction thereof}

This is probably the most down-to-earth view on the function of law. And again, there is no point in denying that law, in whatever function it may appear, has to take into account what Hart called 'the minimum content of natural law'. ${ }^{49}$ It does not have to cater to basic needs itself, obviously. But it should see to it that basic needs are presented and satisfied in an orderly way, given the constraints that people are born into, like limited resources, limited knowledge of consequences over time, limited strength of will, etc. Even (or particularly) if we leave the (nation) state-centered paradigm of law behind, here is a touchstone for the function of law in society at large. But once more the view is too wide, and too unspecific. It requires a deeper analysis regarding its implications, e.g., criteria that distinguish 'order' from 'disorder', or 'basic' from 'higher' needs. I submit that this most down-to-earth view may well be the most puzzling one..$^{\mathbf{o}}$

In conclusion we find that none of these wide, and widely-held, views on the ultimate purpose of law is sufficiently specific to offer a stronghold in cases where different functions collide or where one function is served by other agents and institutions than the juridical ones.

\subsection{An alternative narrow view}

I would like to contrast these wide views with a narrower one: at the core, law (in Western societies) is there to end or prevent conflicts that are potentially disruptive of society, by authoritative (legislative, administrative, or judicial) decision-making. Before I go on to argue why this, admittedly traditional, view is more adequate than its wideranging competitors I would like to clarify how rich it is in its narrowness, thus straightening out some misunderstandings.

(i) Ending/preventing conflict does not entail 'solving' the underlying problem, though solving the underlying problem is a solid way to end/prevent a conflict. An important parameter of satisfying solutions is 'justice' or 'fairness', preferred values that are relevant not only in 
law but also in politics, economics, and ethics. The intention to go beyond the mere end of stopping or curbing a conflict and address the underlying issue explains why there is an increasing interest in Alternative Dispute Resolution (ADR), often 'under the shadow of the law'. It also explains why judges in family law take far more liberty to set formalities aside and go to the heart of the matter than in, say, tax law. But often the law is reluctant to tackle the underlying problem; it settles for just stopping or curbing a fight. And we should not regard this as a failure on the part of the law. There is wisdom in the old saying 'lites finiri oportet' (fightings should stop) because, often enough, a way of dealing with the problem will only be found, if at all, if and when parties return to the practice of daily life instead of staying at the meta-level of dispute. Doing the walk rather than the talk is often important in finding a way out of a predicament in human life, for the simple reason that a lot of our knowing-how (i.e., practical knowledge) is tacit, embodied, and conditional on actual situations. ${ }^{\mathbf{1 1}}$ For instance, when I am hesitant about the correct spelling of a word, it does not help to think harder; it helps to stop thinking and to start writing it; chances are that then I will know. In a similar vein, problems in social relationships may profit from stopping the quarrelling on both sides and getting on.

(ii) Not every conflict is the law's business, though even small conflicts may become socially disruptive. It is a sound sociological insight that conflicts in social relationships are not necessarily bad; they often deepen and enrich such ties. But conflicts, even small ones, tend to drift further and further away from a solution, i.e., get out of hand, the more argumentative fuel is brought to the fire by the parties involved. Indeed, even small conflicts tend to involve more and more parties, to the point where they may wreck whole societies. ${ }^{{ }^{2}}$ Law tries to monitor the type of conflicts that are potentially disruptive on a large scale. This, however, is very much dependent on cultural time and space. For instance, in secular society, blasphemy is unlikely to cause social disruption, whereas in religious societies it will do so quite predictably. As a consequence, there is very limited ground for (criminal) law to interfere in the former, while there is plenty of reason in the latter case. Also linguistic pluralism may be negotiated quite smoothly in one country (Switzerland) and give rise to one constitutional crisis after the other in another one (Belgium).

It requires political sensitivity to assess which conflicts should be engaged by law and which should not. From a judicial point of view, quite a few conflicts in private law root in hurt personal feelings, where damages are claimed for the sheer purpose of getting access to a verdict on 'guilt'. They are unlikely to grow to disruptive proportions by any 'slippery slope' argument. Moreover, slippery slope arguments themselves are not always appropriate. ${ }^{53}$ But they are not insane either. From a legislative viewpoint, however, there is a persistent 
inclination to regulate in view of 'order' rather than 'peace', where the criteria of order are inspired by political priorities rather than the reduction of conflict. I would be hesitant to attribute the predicate 'law' to all these regulations. Many of these are political arrangements which should be left to the political process.

(iii) A priori, there are many ways to end or prevent serious conflict in society, and not all of them are part of law; e.g., insulating or eliminating (one of) the antagonists in the conflict, or providing abundant resources. Law has a specific way with conflicts. It tries to stop or curb them by authoritative decision-making. Therefore, any theory of law (functionalist, evolutionist, economist, etc.) has to usher in an account of authority, quite apart from what is equally necessary, namely a theory of decision-making. For reasons of space, let me focus on the former, i.e., on the old saying quoted famously by Hobbes that it is authority rather than truth that makes law.54

A lot of ground here is covered by Raz's 'service conception' of authority, which is basically an answer to the question what it is to 'follow' authority under conditions of (i) rationality and (ii) freedom. 55 I have little reason to take issue with this account here. It's just that I think that there is yet another question to be asked: what is it to acquire authority? To copy Raz's vocabulary, how do you give other agents reason to waive acting on the balance of their own reasons, and to believe that they will end up acting in accordance with the reasons that apply to them anyway if they follow your directives?

My answer is this; you should bring it about that they trust you with a certain knowledge in finding a way out of their predicament(s) which they do not have at their disposal (yet). It does not necessarily have to be theoretical, explicit and demonstrable knowledge. In most cases it is not. It may well be practical knowledge ('knowing how' rather than 'knowing that') and it may well be tacit, implicit, and embodied.

Because it is practical it is easily confused with 'power': the power to find a way out of the predicament. But power is not the first thing at issue when the issue is a predicament. Arguably, the predicament may be canonically expressed as 'What should I/we do?' It is not, typically, 'What do I/we want to do?' For our wants may be short-sighted, illinformed, or weakly willed, even to the point where they become selfdestructive. We rather ask 'What is the right thing to do', given the kind of agent (singular or plural) we take ourselves to be everything being considered, or on the final count of things. Knowledge that leads us out of this predicament is, I submit, genuine (practical) knowledge - a mode of knowledge that comes (gradually) with experience, training, and critical feedback on consequences. It used to be called peritia. It comes far less, if at all, with accepting (learning) true propositions and rejecting false ones. People in predicaments of various kinds turn to people they trust with peritia in the specific 
circumstances at hand and call them 'authorities' who may be able to 'serve' them. Sometimes they will do this jointly, expecting a service that will benefit them jointly, i.e., that will be 'the right thing to do' for their society at large.

To evoke this kind of trust on the scale on society, and thus to acquire authority, one cannot build on the reasons pro and con a certain policy that are already available in society, since they articulate the very predicament that the parties involved desire wish to escape from. And so authority is acquired by pointing to a viable escape, i.e., to a hole in society's plural identity (as it is laid out in properties and preferences). This hole or, if one prefers, this porosity allows it to relate to its surrounding world in a new way for the future and yet retain the link to the past. In this sense, truth is indeed not the main source of law, while authority is. But from this it does not follow that authority can be accounted for without tying it in with an important mode of knowledge. And what is perhaps most important (and debatable...): once trust is evoked and has taken the form of a commitment to comply with authority for one's own benefit, it entails a default approval of coercion by the members of society. This is neither to say that authority is allowed to apply coercion in all domains of social life, nor that the approval cannot be withdrawn. But, by default, it would be self-contradictory to accept authority A in predicament $\mathrm{S}$ forfeiting the balance of one's own reasons, and then construing the balance of one's own reasons after all, as soon as one dislikes A's directives. I venture that, when it comes to law, coercion follows authority, rather than the other way around..$^{\mathbf{6}}$

\subsection{An alternative narrow view}

I would like to contrast these wide views with a narrower one: at the core, law (in Western societies) is there to end or prevent conflicts that are potentially disruptive of society, by authoritative (legislative, administrative, or judicial) decision-making. Before I go on to argue why this, admittedly traditional, view is more adequate than its wideranging competitors I would like to clarify how rich it is in its narrowness, thus straightening out some misunderstandings.

(i) Ending/preventing conflict does not entail 'solving' the underlying problem, though solving the underlying problem is a solid way to end/prevent a conflict. An important parameter of satisfying solutions is 'justice' or 'fairness', preferred values that are relevant not only in law but also in politics, economics, and ethics. The intention to go beyond the mere end of stopping or curbing a conflict and address the underlying issue explains why there is an increasing interest in Alternative Dispute Resolution (ADR), often 'under the shadow of the law'. It also explains why judges in family law take far more liberty to set formalities aside and go to the heart of the matter than in, say, tax 
law. But often the law is reluctant to tackle the underlying problem; it settles for just stopping or curbing a fight. And we should not regard this as a failure on the part of the law. There is wisdom in the old saying 'lites finiri oportet' (fightings should stop) because, often enough, a way of dealing with the problem will only be found, if at all, if and when parties return to the practice of daily life instead of staying at the meta-level of dispute. Doing the walk rather than the talk is often important in finding a way out of a predicament in human life, for the simple reason that a lot of our knowing-how (i.e., practical knowledge) is tacit, embodied, and conditional on actual situations. $\mathbf{5 7}$ For instance, when I am hesitant about the correct spelling of a word, it does not help to think harder; it helps to stop thinking and to start writing it; chances are that then I will know. In a similar vein, problems in social relationships may profit from stopping the quarrelling on both sides and getting on.

(ii) Not every conflict is the law's business, though even small conflicts may become socially disruptive. It is a sound sociological insight that conflicts in social relationships are not necessarily bad; they often deepen and enrich such ties. But conflicts, even small ones, tend to drift further and further away from a solution, i.e., get out of hand, the more argumentative fuel is brought to the fire by the parties involved. Indeed, even small conflicts tend to involve more and more parties, to the point where they may wreck whole societies. ${ }^{\mathbf{8}}$ Law tries to monitor the type of conflicts that are potentially disruptive on a large scale. This, however, is very much dependent on cultural time and space. For instance, in secular society, blasphemy is unlikely to cause social disruption, whereas in religious societies it will do so quite predictably. As a consequence, there is very limited ground for (criminal) law to interfere in the former, while there is plenty of reason in the latter case. Also linguistic pluralism may be negotiated quite smoothly in one country (Switzerland) and give rise to one constitutional crisis after the other in another one (Belgium).

It requires political sensitivity to assess which conflicts should be engaged by law and which should not. From a judicial point of view, quite a few conflicts in private law root in hurt personal feelings, where damages are claimed for the sheer purpose of getting access to a verdict on 'guilt'. They are unlikely to grow to disruptive proportions by any 'slippery slope' argument. Moreover, slippery slope arguments themselves are not always appropriate. ${ }^{59}$ But they are not insane either. From a legislative viewpoint, however, there is a persistent inclination to regulate in view of 'order' rather than 'peace', where the criteria of order are inspired by political priorities rather than the reduction of conflict. I would be hesitant to attribute the predicate 'law' to all these regulations. Many of these are political arrangements which should be left to the political process. 
(iii) A priori, there are many ways to end or prevent serious conflict in society, and not all of them are part of law; e.g., insulating or eliminating (one of) the antagonists in the conflict, or providing abundant resources. Law has a specific way with conflicts. It tries to stop or curb them by authoritative decision-making. Therefore, any theory of law (functionalist, evolutionist, economist, etc.) has to usher in an account of authority, quite apart from what is equally necessary, namely a theory of decision-making. For reasons of space, let me focus on the former, i.e., on the old saying quoted famously by Hobbes that it is authority rather than truth that makes law. ${ }^{60}$

A lot of ground here is covered by Raz's 'service conception' of authority, which is basically an answer to the question what it is to 'follow' authority under conditions of (i) rationality and (ii) freedom. ${ }^{\mathbf{6 1}}$ I have little reason to take issue with this account here. It's just that I think that there is yet another question to be asked: what is it to acquire authority? To copy Raz's vocabulary, how do you give other agents reason to waive acting on the balance of their own reasons, and to believe that they will end up acting in accordance with the reasons that apply to them anyway if they follow your directives?

My answer is this; you should bring it about that they trust you with a certain knowledge in finding a way out of their predicament(s) which they do not have at their disposal (yet). It does not necessarily have to be theoretical, explicit and demonstrable knowledge. In most cases it is not. It may well be practical knowledge ('knowing how' rather than 'knowing that') and it may well be tacit, implicit, and embodied. Because it is practical it is easily confused with 'power': the power to find a way out of the predicament. But power is not the first thing at issue when the issue is a predicament. Arguably, the predicament may be canonically expressed as 'What should I/we do?' It is not, typically, 'What do I/we want to do?' For our wants may be short-sighted, illinformed, or weakly willed, even to the point where they become selfdestructive. We rather ask 'What is the right thing to do', given the kind of agent (singular or plural) we take ourselves to be everything being considered, or on the final count of things. Knowledge that leads us out of this predicament is, I submit, genuine (practical) knowledge - a mode of knowledge that comes (gradually) with experience, training, and critical feedback on consequences. It used to be called peritia. It comes far less, if at all, with accepting (learning) true propositions and rejecting false ones. People in predicaments of various kinds turn to people they trust with peritia in the specific circumstances at hand and call them 'authorities' who may be able to 'serve' them. Sometimes they will do this jointly, expecting a service that will benefit them jointly, i.e., that will be 'the right thing to do' for their society at large.

To evoke this kind of trust on the scale on society, and thus to acquire 
authority, one cannot build on the reasons pro and con a certain policy that are already available in society, since they articulate the very predicament that the parties involved desire wish to escape from. And so authority is acquired by pointing to a viable escape, i.e., to a hole in society's plural identity (as it is laid out in properties and preferences). This hole or, if one prefers, this porosity allows it to relate to its surrounding world in a new way for the future and yet retain the link to the past. In this sense, truth is indeed not the main source of law, while authority is. But from this it does not follow that authority can be accounted for without tying it in with an important mode of knowledge. And what is perhaps most important (and debatable...): once trust is evoked and has taken the form of a commitment to comply with authority for one's own benefit, it entails a default approval of coercion by the members of society. This is neither to say that authority is allowed to apply coercion in all domains of social life, nor that the approval cannot be withdrawn. But, by default, it would be self-contradictory to accept authority A in predicament $\mathrm{S}$ forfeiting the balance of one's own reasons, and then construing the balance of one's own reasons after all, as soon as one dislikes A's directives. I venture that, when it comes to law, coercion follows authority, rather than the other way around. ${ }^{62}$

\section{Telos and function}

My main argument for a strict account of the purpose of law is a functional one, or so I want to believe. It is the best explanation of a number of properties that we may observe in well-functioning legal orders and that, together, we recognize as a mechanism that warrants the resilience of law as a conflict-resolving system. Without the hypothesis that law is what it is because it is meant to end or prevent potentially disruptive conflict by authoritative decision-making (regarding rules or regarding cases), there would be no reason to retain and protect these features. Let me briefly review some of them.

i. A lot of law has to do with drawing a circle around conflicts that marks the common ground of an arena where the fight has to take place. There is a prescribed language that the parties must speak; they cannot just choose their own words ${ }^{\mathbf{6 3}}$ without a lawyer transforming them into legal categories. This language has a mediating role, in the sense that only by these transformations the conflict may be addressed and decided upon. This comes at the price of alienating effects, where at the end of a law suit the parties involved sometimes barely recognize what kept them divided.

ii. There are strict rules of procedure both for legislative and judicial decision-making, warranting that any problem can be fed into an algorithm that will provide a decision in a finite 
number of steps. The legislator's decisions hinge on majority vote, the judge's decisions of the hierarchy of courts, with one court being supreme. The latter feature, in particular, is very telling. If parties in conflict could shop around for equally high judges, conflicts would not end, let alone be prevented.

iii. Meanwhile, the discursive turns of the procedures (who starts, who is next, etc.) clearly mark the steps to be taken. Time restrictions (terms; due process requirements) work towards reaching a decision, though more so in ending a conflict at hand than in pre-empting foreseeable conflict.

iv. The law of evidence limits the weapons that may be chosen for the procedure, while other rules warrant access to justice (e.g., on legal aid), provide equality of arms, and offer a level battlefield.

v. Legal fictions help to 'construe' a case so that it can be decided upon, even in the absence of hard factual evidence.

Presumptions (juris tantum; juris et de jure) fulfill similar roles. The most robust presumption is that the law always responds to a case, once it is decided that it should be heard. The judge does not have liberty to hide behind the back of the legislator.

vi. Majority vote in democratic (i.e., multi-party) legislation causes pressure groups to abolish the most radical camps in a conflict and to prepare for negotiation and compromise, so as to end up in the majority. But only on condition of another conflict-muting rule; namely that the majority leaves the minority the institutionally warranted chance to become a majority.

vii. Legal rules often appeal to pre-figurations of legal normativity in society (the foresight of a reasonable man; good entrepreneurship; normal conditions; etc.), so as to channel social behavior before it ushers in conflict. At the same time, the normative meaning of these pre-figurations in law remains to be set (i.e., posited) by legal officials.

viii. On a larger canvass, this double bind of law becomes visible in the bi-conditional relationship between subjective rights and objective law: no subjective rights without the sanction of objective law, but then no objective law without respect for subjective rights. ${ }^{64}$

ix. In principle, coercion is applied only under the restraints that come with the legal institutionalization of authority, i.e., competence. 
$\mathrm{x}$. In principle, where no socio-political conflicts are to be expected, (criminal) law is inclined to step back and monitor the boundaries of an emergent normative domain rather than what goes on in the domain itself. Cf. euthanasia under well-defined circumstances as essentially different from murder on the one hand and assisted suicide on the other.

xi. Abundant theatrical stage settings undergird the authority of parliament, government, and judicature, as if these bodies are acquainted with a wider world beyond society.

These (and other) features would be incomprehensible if the wide views of section 2.1 would dominate the ultimate telos of law. In particular, if law would be primarily an instrument of regulating sociopolitical behavior in a society, it would often come at loggerheads with strict procedures, established language, restraint coercion, etc. And if it would be primarily about securing a sort of minimum morality in society, it would refrain from what Luhmann calls 'Vollpositivierung' ${ }^{\mathbf{6 5}}$, as well as from fictions and presumptions that somehow tinker with facts on the ground. Moreover it would be much more deliberative than decisive in the face of contested values. ${ }^{\mathbf{6 6}} \mathrm{By}$ contrast, these - and countless other - properties of law speak to law as a resilient phenomenon in our society, as they together form a mechanism that generates authoritative final decisions in cases of serious societal conflict.

One last question: What depends on a wider or a narrower view on the telos of law and its basis in a functional mechanism of resilience? I think that the narrow view could inspire at least some fundamental changes in our manifold appeals to law, as we tend to use it to solve problems for which it is inappropriate. The decisive parameter for these changes is the extent to which socially disruptive conflicts are (or come) in sight. Firstly, in many areas of socio-political life, e.g., in medical and social care and nursery, we witness a proliferation of (quasi-)legal categories in making moral and/or professional judgments. That is to say, increasingly, good care is tantamount to protocol and procedure rather than attentiveness and prudence. Binaries like capability/incapability (of will) govern many a moral decision, where only shades and modes of willing would do justice to the situation at hand.

Secondly, and surprisingly, perhaps, it is also unnecessary, indeed counterproductive, to make law the default mode of public regulation. Other arrangements are conceivable, especially those that keep conflicts at bay. Major cities in the world today are governed not so much through law as by involving key players in wide-ranging agreements from which they all profit, individually and jointly. There is rare need to cast these agreements in the mold of law, following set 
procedures, attributing liabilities, competences, sanctions, etc. beforehand. It would make them less flexible, e.g., in profiting from rapidly changing circumstances. Like in traffic, it is often better to create a roundabout where all players cannot but carefully watch and negotiate each other's behavior, than to put up lights from which they can infer rights (and fights).

Thirdly, and this is no surprise, it is rewarding to continue on the path of ARD, and curb litigation where possible. Authoritative decisionmaking to end a conflict is rarely the best way to solve the underlying problem. Also, even in law suits judges should encourage parties to compromise, rather than litigate. And they should not be sanctioned for doing so by the court's management, for the sole reason of saving time and money.

On the other hand, if we'd choose to continue on the path of using law for purposes and in contexts which it would be better kept away from, we will predictably run into one or more traps of the following kind(s):

1. We will perpetually struggle to keep legal protection up over and against political expediency (instrumentalism).

2. We will increasingly define our social relationships from what can go wrong with them, i.e., from the point of view of mutual distrust.

3. We will construe their predicaments in the 'winner takes all' binary of a law suit, rather than the win-win outcomes of compromises.

4. We will continue to bring 'discursive dilemmas' ${ }^{\mathbf{6}}$ out of sight by preferring individualized reasoning on group issues.

5. We will hold agents liable who are not and not hold agents liable who are, e.g., by the straightjacket of (linear) causality as prescribed by law - all in good faith that we are solving political problems by legal rules.

6. We will evaluate the performance of law by the wrong standards.

\section{References}

\section{Alexy 2002}

R. Alexy, A theory of constitutional rights, Oxford/New York: Oxford University Press 2002.

\section{Arendt 1973 (1951)}

H. Arendt, The Origins of Totalitarianism. New edition with added 
prefaces, New York/London: Harcourt Brace Jovanovich 1973 (1951).

\section{Castañeda 1975}

H.-N. Castañeda, Thinking and Doing: The Philosophical

Foundations of Institutions, Dordrecht/Boston: Reidel 1975.

\section{Emmet 1967}

D.M. Emmet, 'Functionalism in sociology', in: P. Edwards (ed.), The Encyclopedia of Philosophy, New York/London: MacMillan 1967, $p$. 256-259.

\section{Foqué \& 't Hart 1990}

R. Foqué \& A.C. 't Hart, Instrumentaliteit en rechtsbescherming.

Grondslagen van een strafrechtelijke waardendiscussie, Arnhem:

Gouda Quint/Antwerpen: Kluwer Rechtswetenschappen 1990.

\section{Habermas 1992}

J. Habermas, Faktizität und Geltung. Beiträge zur Diskurstheorie des Rechts und des demokratischen Rechtsstaats, Frankfurt a.M.:

Suhrkamp Verlag 1992.

\section{Habermas \& Luhmann 1971}

J. Habermas \& N. Luhmann, Theorie der Gesellschaft oder Sozialtechnologie. Was leistet die Systemforschung? (Theorie Diskussion), Frankfurt a.M.: Suhrkamp Verlag 1971.

\section{Hart 1961}

H.L.A. Hart, The Concept of Law, Oxford: Clarendon Press 1961.

\section{Hobbes 1973 (1651)}

T. Hobbes, Leviathan. Introd. by K.R. Minogue, London/New York: Everyman's Library 1973 (1651).

\section{Jolls, Sunstein \& Thaler 1998}

C. Jolls, C.R. Sunstein \& R.H. Thaler, 'A Behavioral Approach to Law and Economics', Stanford Law Review 19998,p. 1471-1550.

\section{Kaplow \& Shavell 2002}

L. Kaplow \& S. Shavell, Fairness vs Welfare, Cambridge, MA/London: Harvard University Press 2002.

\section{Le Bouthillier et al. 2012}

$Y$. Le Bouthillier et al. (eds.), Poverty Alleviation and Environmental Law, Cheltenham/Northampton, MA: Edward Elgar 2012.

\section{Lindahl 2013}

H.K. Lindahl, Fault Lines of Globalization: Legal Order and the Politics of A-Legality, Oxford: Oxford University Press 2013. 


\section{Luhmann 1981}

N. Luhmann, 'Subjektive Rechten: Zum Umbau des

Rechtsbewusstseins für die moderne Gesellschaft', in: ID.,

Gesellschaftsstruktur und Semantik: Studien zur Wissenssoziologie der modernen Gesellschaft, vol. 2, Frankfurt a.M.: Suhrkamp Verlag 1981, p. 45-104.

\section{Luhmann 1987}

N. Luhmann, Rechtssoziologie, Opladen: Westdeutscher Verlag 1987.

\section{Maus 1994}

I. Maus, 'Volkssouveränität versus Konstitutionalismus. Zum Begriff einer demokratischen Verfassung', in: G. Frankenberg (ed.), Aufder Suche nach der gerechten Gesellschaft, Frankfurt a.M.: Fischer Taschenbuch Verlag 1994, p. 74-83.

\section{Nagel 1956}

E. Nagel, Logic without Metaphysics and Other Essays in the Philosophy of Science, Glencoe, IL: The Free Press 1956.

\section{Paton \& Denoon 2011}

M. Paton \& A. Denoon, 'The Ramifications of the Advocate General's Opinion in the Olivier Brüstle Case', European Intellectual Property Review 2011, p. 590-596.

\section{Pettit 2000}

P. Pettit, A Theory of Freedom: From the Psychology to the Politics of Agency, Oxford: Oxford University Press 2000.

\section{Polanyi 1962 (1958)}

M. Polanyi, Personal Knowledge: Towards a Post-Critical

Philosophy, London: Routledge and Kegan Paul 1962 (1958).

\section{$\operatorname{Raz} 1984$ (1979)}

J. Raz, The Authority of Law: Essays on Law and Morality. Oxford:

Oxford University Press 1984 (1979).

\section{Raz 2009}

J. Raz, Between Authority and Interpretation: On the Theory of Law and Practical Reason, Oxford: Oxford University Press 2009.

\section{Ricoeur 1990}

P. Ricoeur, Soi-même comme un autre, Paris: Du Seuil 1990.

\section{Rousseau 1964 (1762)}

J.-J. Rousseau, Du contrat social; ou principes du droit politique, Paris: Gallimard 1964 (1762). 


\section{Rowlands 2010}

M. Rowlands, The New Science of the Mind: From Extended Mind to Embodied Phenomenology, Cambridge, MA/London: The MIT Press 2010 .

\section{Schauer 1985}

F. Schauer, 'Slippery slopes', Harvard Law Review 1985, p. 361-383.

\section{Schreckenberger 1978}

W. Schreckenberger, Rhetorische Semiotik: Analyse von Texten des Grundgesetzes und von rhetorischen Grundstrukturen der Argumentation des Bundesverfassung, Freiburg/Munich: Alber 1978.

\section{Shavell \& Polinsky 2007}

S. Shavell \& A.M. Polinsky, Handbook of Law and Economics, Amsterdam: Elsevier 2007.

\section{Shklar 1964}

J. Shklar, Legalism, Cambridge, MA: Harvard University Press 1964.

\section{Summers 1982a}

R.S. Summers, Instrumentalism and American Legal Theory, Ithaca, NY/London: Cornell University Press 1982.

\section{Summers 1982b}

R.S. Summers, 'Pragmatic Instrumentalism and American Legal Theory: A Summary Statement', Rechtstheorie 1982, p. 257-268.

\section{Twining \& Miers 1991}

W. Twining \& D. Miers, How to Do Things with Rules: A Primer of Interpretation, London: Weidenfeld and Nicholson 1991.

\section{Van der Burg 1991}

W. van der Burg, 'The slippery slope argument', Ethics 1991, p. 42-65.

\section{Van Roermund 2013}

B. van Roermund, 'Rules as Icons: Wittgenstein's Paradox and the Law', Ratio Juris2o13, p. 538-559.

\section{Waldenfels 2001}

B. Waldenfels, Verfremdung der Moderne. Phänomenologische Grenzgänge, Göttingen: Wallstein Verlag 2001.

\section{Witteveen 2015}

W. Witteveen, De wet als kunstwerk. Een andere filosofie 
van het recht. Hoe de filosofen onze wetgevers de maat nemen, Amsterdam: Boom 2015.

Wittgenstein 1953

L. Wittgenstein, Philosophical

Investigations/Philosophische Untersuchungen, Oxford: Blackwell 1953.

\section{Noten}

* This paper is a rewritten version of a presentation I gave at the 5th MetaLawEcon workshop What is law for?, 11-12 December 2014, University of Debrecen Faculty of Law. I would like to thank the conveners of this workshop, Peter Cserne and Mariusz Golecki, for having me as an invited speaker, and the participants for various useful comments. I also thank mrs. Anneke Stigter for linguistic corrections.

1 In Nagel 1956.

2 Emmet 1967, p. 258.

3 Pettit 2oo2, p. 247.

4 Pettit 2oo2, p. 253.

5 Rousseau 1964 (1762), vol. 2, p. 11.

6 Rousseau 1964 (1762), vol. 3, p. 9.

7 The question arises if such neutrality makes functionalism a solid partner in doctrinal legal scholarship?

8 One is reminded of Wittgenstein 1953, par 124:

'Philosophy may in no way interfere with the actual use of language; it can in the end only describe it. (...) It leaves everything as it is.'

9 There is a vast body of literature on this mode of intentionality. I refer to work by Bratman, Gilbert, Pettit, Searle, Tuomela, and many others. See also the accumulated literature in the bibliography at $<$ www.helsinki.fi/ pylikosk/collint/>.

10 Waldenfels $2001,140$.

11 On the reflexivity of intentions see Castañeda 1975 and his earlier papers referred to there; similar arguments are 
made by Pettit, e.g., Pettit 2ooo, p. 8off.

12 Cf. Ricoeur 1990 and references there.

13 Note that in Aristotelian ontology, telos is inherently reflexive. For its point that everything strives towards some purpose, or a purpose, but towards its (own) purpose.

14 Commenting on Nagel, Emmet (1967) concluded, that it is misleading to speak of the function of a practice, belief, or institution tout court. It may have a function in relation to a certain interest in a certain context, and this itself may be a disfunction in relation to other interests'. She also emphasizes that, all in all, functional accounts in sociology '(...) even if they are not themselves teleological, carry an indirect teleological implication in that if something is said to have a function, it has one in relation to some value, interest, or purpose held by some person or group within the society (...). Where no value is stated, the presumption tends to be that what is served is the preservation of the society as an ongoing concern.'

15 Obviously, this is particularly a tenet of economic analysis of law, or more generally, a social science approach to law. Cf. Shavell \& Polinsky 2007 in their Preface (p. xi): 'Law can be viewed as a body of rules and legal sanctions that channel behavior in socially desirable directions - for example, by encouraging individuals to take proper precautions to prevent accidents or by discouraging competitors from colluding to raise prices.' Famously, Kaplow \& Shavell 2002 argued that there is no specific meaning in fairness that could not be covered by 'welfare' as analyzed by economics; i.e., that law is ultimately about welfare behavior. Because economic analysis of law increasingly integrates the 'behavioral turn' in economics generally (buzzword 'behavioral economics'), this alleged role of law has appeared in a new key. For a seminal paper see already Jolls, Sunstein \& Thaler 1998.

16 The roots of this conception lie in the idea of law as a matter of 'social engineering' (Roscoe Pound), adequately captured and modernized by Summers 1982a and $1982 \mathrm{~b}$. Exclusively instrumentalist versions of this basically sound conception were criticized in The Netherlands by Foqué \& 't Hart 1990 and recently by Witteveen 2015; see literature there. 
17 Not surprisingly (see below under (3)), this view is in the background, primarily, of research in specific legal areas, such as environmental law, labor law, IP law, health law, and their ilk. It should be distinguished from, on the one hand, economic analysis of law, and, on the other, from Robert Alexy's theory of constitutional rights as 'optimizing principles'. Cf. Alexy 2002.

18 Although the volume is on environmental law, the statement on law in general at (Y Le Bouthillier, Alfie Cohen, M. et al. 2012), p. 17 is a fine example of this basically natural law view: 'Distributive justice represents an ethical imperative based on the notion of moral reciprocity, in which all human beings are treated as equals. (...) Since all human beings are born free and equal in dignity and rights, values and policies should be legitimized through individual consent, equal rights, and democratic procedures rather than through utilitarian philosophies based on abstract notions of welfare or economic efficiency.'

19 Biotechnology Directive 98/44, which is said to have 'generated some of the most intensive debates in $E U$ political history' (Paton \& Denoon 2011, p. 519).

20 Cf. European Court of Justice 18 October 2013, case C34/1o (Brüstle/Greenpeace).

21 Cf. Twining \& Miers 1991.

22 Cf. Van Roermund 2013.

23 In this sense Dworkin was right about principles (and rights) as trumps on policies.

24 Cf. Arendt 1973 (1951), p. 299; see also Lindahl 2013.

25 Habermas 1992; Maus 1994; Schreckenberger 1978.

26 Hart 1961, p. 189ff.

27 The greatest difficulty, however, which also Hart passes by in silence, comes with the functional meaning of needs from a first-person vantage point: what else do they command than their satisfaction? Self-preservation perhaps? Then how would one construe selfhood from sheer needs? 
28 Cf. Polanyi 1962 (1958); for recent revival of embodied knowledge see, a.o., Rowlands 2010.

29 Cf. the paradigmatic tale of 'The shadow of a donkey', in particular in the elaborated version by Christoph Martin Wieland (1733-1813) in Die Abderiten, Book IV: Der Process um des Esels Schatten, where the name of the man who rented the donkey is Struthion, and the name of the donkey's owner is Anthrax.

30 Cf. a.o., Schauer 1985; Van der Burg 1991.

31 Hobbes 1973 (1651), ch. XXVI.

$32 \operatorname{Raz} 1984$ (1979) and 2009.

33 Cf. Rousseau 1964 (1762): on the basis of the social contract, coercion amounts to 'forcing someone to be free'.

34 On the reflexivity of intentions see Castañeda 1975 and his earlier papers referred to there; similar arguments are made by Pettit, e.g., Pettit 20oo, p. 8off.

$35 C f$. Ricoeur 1990 and references there.

36 Note that in Aristotelian ontology, telos is inherenty reflexive. For its point that everything strives towards some purpose, or a purpose, but towards its (own) purpose.

37 Commenting on Nagel, Emmet (1967) concluded, that it is misleading to speak of the function of a practice, belief, or institution tout court. It may have a function in relation to a certain interest in a certain context, and this itself may be a disfunction in relation to other interests'. She also emphasizes that, all in all, functional accounts in sociology '(...) even if they are not themselves teleological, carry an indirect teleological implication in that if something is said to have a function, it has one in relation to some value, interest, or purpose held by some person or group within the society (...). Where no value is stated, the presumption tends to be that what is served is the preservation of the society as an ongoing concern.'

38 Obviously, this is particularly a tenet of economic analysis of law, or more generally, a social science approach to law. Cf. Shavell \& Polinsky 2007 in their Preface (p. xi): 'Law can be viewed as a body of rules and 
legal sanctions that channel behavior in socially desirable directions - for example, by encouraging individuals to take proper precautions to prevent accidents or by discouraging competitors from colluding to raise prices.' Famously, Kaplow \& Shavell 2002 argued that there is no specific meaning in fairness that could not be covered by 'welfare' as analyzed by economics; i.e., that law is ultimately about welfare behavior. Because economic analysis of law increasingly integrates the 'behavioral turn' in economics generally (buzzword 'behavioral economics'), this alleged role of law has appeared in a new key. For a seminal paper see already Jolls, Sunstein \& Thaler 1998.

39 The roots of this conception lie in the idea of law as a matter of 'social engineering' (Roscoe Pound), adequately captured and modernized by Summers 1982a and $1982 b$. Exclusively instrumentalist versions of this basically sound conception were criticized in The Netherlands by Foqué \& 't Hart 1990 and recently by Witteveen 2015; see literature there.

40 Not surprisingly (see below under (3)), this view is in the background, primarily, of research in specific legal areas, such as environmental law, labor law, IP law, health law, and their ilk. It should be distinguished from, on the one hand, economic analysis of law, and, on the other, from Robert Alexy's theory of constitutional rights as 'optimizing principles'. Cf. Alexy 2002.

41 Although the volume is on environmental law, the statement on law in general at (Y Le Bouthillier, Alfie Cohen, M. et al. 2012), p. 17 is a fine example of this basically natural law view: 'Distributive justice represents an ethical imperative based on the notion of moral reciprocity, in which all human beings are treated as equals. (...) Since all human beings are born free and equal in dignity and rights, values and policies should be legitimized through individual consent, equal rights, and democratic procedures rather than through utilitarian philosophies based on abstract notions of welfare or economic efficiency.'

42 Biotechnology Directive 98/44, which is said to have 'generated some of the most intensive debates in $E U$ political history' (Paton \& Denoon 2011, p. 519). 
34/1o (Brüstle/Greenpeace).

$44 C f$. Twining \& Miers 1991.

45 Cf. Van Roermund 2013.

46 In this sense Dworkin was right about principles (and rights) as trumps on policies.

47 Cf. Arendt 1973 (1951), p. 299; see also Lindahl 2013.

48 Habermas 1992; Maus 1994; Schreckenberger 1978.

49 Hart 1961, p. $189 f f$.

50 The greatest difficulty, however, which also Hart passes by in silence, comes with the functional meaning of needs from a first-person vantage point: what else do they command than their satisfaction? Self-preservation perhaps? Then how would one construe selfhood from sheer needs?

51 Cf. Polanyi 1962 (1958); for recent revival of embodied knowledge see, a.o., Rowlands 2010.

52 Cf. the paradigmatic tale of 'The shadow of a donkey', in particular in the elaborated version by Christoph Martin Wieland (1733-1813) in Die Abderiten, Book IV: Der Process um des Esels Schatten, where the name of the man who rented the donkey is Struthion, and the name of the donkey's owner is Anthrax.

53 Cf. a.o., Schauer 1985; Van der Burg 1991.

54 Hobbes 1973 (1651), ch. XXVI.

$55 \operatorname{Raz} 1984$ (1979) and 2009.

56 Cf. Rousseau 1964 (1762): on the basis of the social contract, coercion amounts to 'forcing someone to be free'.

57 Cf. Polanyi 1962 (1958); for recent revival of embodied knowledge see, a.o., Rowlands 2010.

$58 \mathrm{C}$. the paradigmatic tale of 'The shadow of a donkey', in particular in the elaborated version by Christoph Martin Wieland (1733-1813) in Die Abderiten, Book IV: Der Process um des Esels Schatten, where the name of the man who 
rented the donkey is Struthion, and the name of the donkey's owner is Anthrax.

59 Cf. a.o., Schauer 1985; Van der Burg 1991.

$6 o$ Hobbes 1973 (1651), ch. XXVI.

$61 \operatorname{Raz} 1984$ (1979) and 2009.

62 Cf. Rousseau 1964 (1762): on the basis of the social contract, coercion amounts to 'forcing someone to be free'.

63 As is often the case in hearings taking place in a Truth and Reconciliation setting.

64 Luhmann 1981, p. $46 f f$.

65 Cf. a.o., Luhmann 1987, p. 201; on a thumbnail: 'Recht gilt weil es gilt'.

66 If I would dare to criticize Habermas's theory of law, it would be that he does not give any account of the transition from deliberation to decision. Note that Habermas's early work characterizes Diskurs as 'Gegeninstitution schlechthin' (Habermas \& Luhmann 1971, p. 201), where later on (Habermas 1992) he applies it to law - for many theorists the paragon of institutions. He seems to think that in law a decision is but a conchsion from a deliberation. Some legal theorists have learnt to reject this as 'legalism'. Cf. Shklar 1964.

67 Cf. Pettit 2ooo, p. 106ff and references there. 